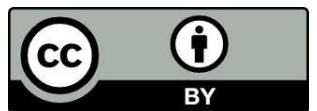

\title{
FORÇAS ARQUETÍPICAS E SUAS SOMBRAS PROJETADAS NO ESPAÇO
}

\author{
Archetypal Forces and Their Shadows Projected Through Space
}

\author{
Emerli Schlögl \\ Mestre em Educação pela PUCPR \\ Doutora em Geografia pela UFPR \\ Professora da EMBAP \\ emerlischlogl@hotmail.com
}

\begin{abstract}
RESUMO: O presente artigo aborda a Geografia da Religião em diálogo com a Psicologia Analítica de Jung. Discorremos sobre arquétipos e sobre as projeções inconscientes, principalmente formadas por elementos que constituem o que Jung denominou de sombras, e que podem influenciar na conformação de espacialidades religiosas, imprimindo-lhes características peculiares. Para tanto, localizamos e conceituamos o símbolo apontando para a sua importância no estudo e pesquisa da Geografia da Religião. Diferenciamos o símbolo do sinal, seguindo o raciocínio de Jung e Cassirer. Para favorecer a construção desta reflexão apresentamos uma síntese da constituição da psique humana em seu formato individual e coletivo, conforme teoria desenvolvida por Jung. Por fim, analisamos resultados das projeções da sombra nas conformações de espacialidades religiosas, tomando como exemplo um recorte histórico da Fé Bahá'í.
\end{abstract}

Palavras chave: Arquétipos; espacialidades; sombras; Geografia da Religião; Psicologia Analítica.

ABSTRACT: This article discusses the Geography of Religion in dialogue with the Analytic Psychology of Jung. We speak about archetypes and the unconscious projections, mainly formed by elements that constitute what Jung called shadows, and that they may influence the conformation of religious space, giving them peculiar characteristics. To do so, we locate and conceptualize the symbol pointing to its importance in the study and research of Geography of Religion. We distinguish the symbol from the sign, following the reasoning of Jung and Cassirer. In order to favor the construction of this reflection we present a summary of the constitution of the human psyche in its individual and collective format, as theory developed by Jung. Finally, we analyze the results of the projections of the shadow on the conformations of religious space, taking as an example one historical clip of the Bahá ' $i$ faith.

Keywords: Archetypes, space, shadows, geography of religion, analytical psychology. 


\section{INTRODUÇÃO}

No estudo das espacialidades nos deparamos com códigos culturais, ou seja, com símbolos que traduzem formas de pensamento/sentimento do humano em relação ao mundo em que habita. O mundo habitado é compreendido e transformado pelos seres vivos. Os seres humanos, em especial, criam a cultura e são influenciados por ela. Para Bonnemaison (2002) a cultura ao penetrar o espaço geográfico "desenha no solo uma semiografia feita de um entrelaçamento de signos, figuras e sistemas espaciais que são a representação, arrisquemos a palavra, 'geosimbólica' da concepção que os homens fazem do mundo e de seus destinos" (p.105).

O espaço geográfico dá suporte às mitologias com seus símbolos coletivos, frutos do imaginário e a tantas outras expressões não materiais que imprimem por meio do ato humano, também motivado por forças arquetípicas, elementos que conformam espaços sagrados e para Gil Filho (2008) o espaço sagrado atua como estrutura estruturante $^{1}$ da esfera religiosa.

$\mathrm{O}$ inconsciente ${ }^{2}$ ao se expressar de modo simbólico revela movimentos que acontecem no subterrâneo do funcionamento psíquico, no inconsciente, e por isso não se limitam à razão. Assim, os mitos carregados de sentimentos e significados diversos originam-se no misterioso mundo psíquico e a ele retornam. Fries (1970) afirma que o mistério "é o que escapa, definitivamente ou provisoriamente às exigências da ratio, ávida de compreender, de dominar e de se apropriar totalmente de seu objeto". (p. 316). Assim, a racionalidade tangencia o mistério, mas os sentimentos o penetram.

A experiência mística conduz a pessoa a um estado afetivo que sugere uma imersão no inconsciente e a vivência de uma realidade que transcende o conhecido da vida cotidiana. Como exemplo podemos citar a experiência de um menino de nove anos da nação dos Sioux:

\footnotetext{
1 Tomando o conceito de estrutura estruturante de Bourdieu (1980), pode-se compreender que há uma interação de forças que estabelecem reciprocidades nas relações. O termo estruturas refere-se a disposições interiorizadas e duráveis e o termo estruturantes refere-se àquilo que gera práticas e representações. Os indivíduos e comunidades estão inseridos em uma estrutura com força estruturante, e isto define os campos, nestes particular, as espacialidade.

${ }^{2}$ Jung (1985) coloca que a palavra inconsciente não foi uma invenção freudiana, o termo já era conhecido anteriormente na filosofia alemã. Kant e Leibniz tinham definições próprias para ele. Afirma que na filosofia alemã o inconsciente é visto sob a perspectiva do movimento dinâmico da psique apresentando aspectos desconhecidos para a instância consciente da psique.
} 
Eu vi a mim mesmo na montanha do centro do mundo, o lugar mais alto e tive uma visão, porque estava vendo do modo sagrado de ver o mundo'. A montanha sagrada do centro do mundo à qual ele se referia era o Harney Peak, Dakota do Sul. E então ele diz: "Mas a montanha do centro do mundo está em toda a parte (CAMPBELL, 1993, p. 93).

A experiência mística se relaciona a uma dada geografia, é uma experiência espiritual enraizada em uma espacialidade concreta por meio da expressão simbólica. A experiência do mistério necessita do suporte da materialidade para poder encontrar expressão, isto significa que os rios, pedras, montanhas, planícies, etc., se revestem de sentido simbólico, tomando do espaço o seu anonimato e lhe imprimindo uma personalidade própria. Assim as espacialidades religiosas têm também seu nascedouro nas fontes primitivas do inconsciente, de onde a religião encontra elementos para tornarse texto, no contexto do espaço.

Por exemplo: certas epifanias se dão no alto de uma montanha, e estão associadas à ideia do contato do humano com o superior, com o elevado. O menino Sioux teve a experiência mística de totalidade, no alto de uma montanha, Moisés recebeu os dez mandamentos no alto do monte Sinai, assim sucedeu com outros personagens importantes no mundo religioso. "Entre alguns povos, há também a crença, sem evidência geográfica, de que eles vivem no topo do mundo, ou de que seu lugar sagrado está no cume da Terra"(TUAN,1983, p.44).

Estes pensamentos simbólicos surgem como resultantes da tomada de consciência de realidades interiores, e além de simbolismos individuais, podemos nos deparar com simbolismos coletivos, comuns à espécie humana. Conforme JUNG (1977) os símbolos apontam para direções diferentes das direções percebidas pela mente consciente, relacionam-se com coisas inconscientes ou então parcialmente conscientes. Como já afirmamos, a forma científica lógica não possui os instrumentos completos para a leitura simbólica: a imaginação e a intuição são indispensáveis para o processo de entendimento desta dimensão (SCHLÖGL, 2005).

Entendemos que todo o processo de conscientização dos elementos inconscientes necessita do espaço exterior para ocorrer. Portanto, os arquétipos são também forças delineadoras de espacialidades.

Segundo Jacobi (1990) Jung tirou o temo "arquétipo", adotado desde 1927 do Corpus Hermeticum (II,140.22 ed. Scott), assim como do De divinis nominibus (cap. 2 
§6), de Dionísio Areopagita, e também as ideae principales, de Agostinho, que o estimularam na escolha do termo.

A noção de arquétipo, expresso em imagens que Jung designava inicialmente como 'motivos de modelos' psíquicos, com o correr do tempo se estendeu a todos os tipos de modelos, configurações, decorrências, etc., isto é, também aos processos dinâmicos e não apenas às imagens estáticas. No fim de tudo, foram incluídas todas as manifestações psíquicas da vida, desde que sejam comuns e típicas da natureza humana, tanto no nível biológico e psicobiológico, como no nível de formação de ideias (JACOBI, 1990, p. 40).

Neumman (2006) afirma que o simbolismo dos arquétipos "se manifesta sob a forma de imagens psíquicas específicas, que são percebidas pela consciência e peculiares a cada arquétipo" (p. 19). Os símbolos derivados deste arquétipo, estes "cânones simbólicos", como os denominou Neumman (2006, p. 21), recebem inúmeras formas: Uroboros, Gaia, O Vaso, Kali, Noite, Morte, grande Círculo, Ísis, Árvore, Lua, Água, Montanha, Abelha, Aranha, Xamã, Bruxa, Kwan-yin, entre tantas outras.

O círculo, como imagem arquetípica, tem a propriedade de conter todos estes símbolos, de traçar limites na terra. Neste sentido o círculo de Gaya é o suporte material do organismo psíquico e físico da vida, pois “(...) o centro elementar do círculo tem a função de conter" (NEUMMAN, 2006, p. 65).

O espaço, a partir do momento em que contem elementos que sustentam uma identidade própria, se espacializa. $\mathrm{Na}$ espacialização da religião os símbolos arquetípicos são imprescindíveis para a formação de uma unidade entre sentimento, pensamento, ação, tempo e espaço.

Jung (1977) compreendeu por meio de seu minucioso estudo sobre símbolos, especialmente os religiosos, que estes trazem uma considerável porção de energia psíquica, de forma condensada, e que no estabelecimento do contato do ser humano com estes símbolos, no relacionamento que implica em compreensões e sentimentos, estabelece-se uma possibilidade de maior compreensão de si mesmo.

Por meio das representações simbólicas que personalizam as espacialidades, os seres humanos "reimaginam" as suas relações sociais e relações espaciais. Nelas estão embutidos conceitos que organizam e definem as relações entre os gêneros, entre o humano e o divino, entre os elementos da natureza, etc. 
Deste modo, compreender as espacialidades religiosas por meio das representações simbólicas arquetípicas, veiculadas pelos mitos, corporificadas nos ritos e traduzidas em comportamentos sociais, significa um exercício psico-geográfico.

A sacralização da paisagem local é uma função fundamental da mitologia. Você vê isso claramente nos navajos, capazes de identificar uma montanha do norte, uma montanha do sul, uma montanha do leste, uma montanha do oeste e uma montanha do centro. Numa habitação navaja, a porta sempre está voltada para o leste. A lareira se localiza no centro, que se torna um centro cósmico, e a fumaça sobe para um buraco aberto no teto, de modo que o aroma do incenso se dirija diretamente às narinas dos deuses. A paisagem, o lugar de morada, se torna um ícone, uma figura sagrada. Onde quer que esteja, você estará conectado com a ordem cósmica. Observe uma pintura de areia navaja, verá que há sempre uma figura circundante - pode representar uma miragem, o arco-íris, o que seja, mas haverá sempre uma figura circundante, aberta do lado leste, para que o espírito novo possa penetrar por ali. Quando o Buda se sentou sob a árvore, voltou sua face para o leste - a direção do sol nascente (CAMPBELL,1993, p. 97).

A energia arquetípica do símbolo colabora para a sacralização do espaço e dos elementos. "Antes de ser um espetáculo consciente, toda paisagem é uma experiência onírica" (BACHELARD, 2002, p. 5). A partir disto podemos dizer que a experiência onírica, inconsciente, emerge no consciente e se materializa no espaço, conformando as espacialidades religiosas, entre outras.

\section{FUNDAMENTOS EPISTEMOLÓGICOS PARA A REALIZAÇÃO DE UMA LEITURA GEOGRÁFICA DOS ARQUÉTIPOS}

Encontra-se em Cassirer e em Jung a mesma singularidade conceitual que realiza a diferenciação entre os sinais e os símbolos. Cassirer (1997) afirma a realidade humana enquanto realidade construída, nela o ser humano cria novas dimensões de realidade. Neste sentido, podemos afirmar que as espacialidades criadas pelos seres humanos se constituem também em novas dimensões de realidade. Nelas, os símbolos se apresentam em suas características polissignificativas, versáteis, móveis e sempre dinâmicas. 
Segundo Kast (1994), na interpretação simbólica de base junguiana há uma distinção evidente e clara entre sinal e símbolo. Símbolos e sinais possuem conceituações próprias. $\mathrm{O}$ autor define que o símbolo exerce a função de substituir o objeto, e ao fazê-lo realiza uma abstração. A abstração exige relacionar diferentes ideias e entendimentos originados a partir de um significante, de um objeto de representação. Isto nos conduz a uma pluridimensionalidade conceitual e por consequência, a uma gama imensa de possibilidades afetivas e intelectivas na relação que os seres humanos estabelecem com os seus símbolos.

Os sinais, em contraposição, têm significados fixados por meio de uma declaração, não possuem outros significados, não há nada encoberto. Por exemplo: uma placa de trânsito é vista como sinal, define uma única interpretação possível e dirige os seres humanos para uma única ação desejada. Assim, enquanto o símbolo é enigmático e encobre uma multiplicidade de interpretações, o sinal indica a possibilidade de apenas um sentido interpretativo.

Ao estudar o simbólico em Cassirer verifica-se que também para Cassirer os símbolos e os sinais constituem dois universos diferenciados. Os símbolos não se reduzem a sinais, os sinais fazem partem do mundo físico do ser enquanto que os símbolos pertencem ao mundo dos significados, do Logus.

\footnotetext{
Os símbolos - no sentido próprio do termo - não podem ser reduzidos a meros sinais. Sinais e símbolos pertencem a dois universos diferentes de discurso: um sinal faz parte do mundo físico do ser; um símbolo é parte do mundo humano do significado. Os sinais são "operadores" e os símbolos são "designadores". Os sinais, mesmo quando entendidos e usados como tais, têm mesmo assim uma espécie de ser físico ou substancial; os símbolos têm apenas um valor funcional (CASSIRER, 1997, p. 58).
}

Buscando as possíveis origens desta assertiva conceitual encontramos as bases teóricas que as alinham em Platão e em Agostinho. Na obra "Fédon" Platão (1983) narra os momentos que precederam a morte de Sócrates. Trata-se de um relato de Fédon (discípulo de Sócrates) a Equécrates. No subcapítulo intitulado "Os Contrários", encontramos a ideia de simbolo quando Sócrates fala acerca de algo concreto que remete a outro algo: 
rememoração? Que circunstâncias sejam essas, vou dizer-te: se vemos ou ouvimos alguma coisa, ou se experimentamos não importa que outra espécie de sensação, não é somente a coisa em questão que conhecemos, mas temos também a imagem de uma outra coisa, que não é objeto do mesmo saber, mas de outro. Então, dize-me, não temos razão em pretender que aí houve uma recordação, e uma recordação daquilo mesmo de que tivemos a imagem? (PLATÃO, 1983, p. 76).

O texto refere-se a um igual que, porém, é diferente, refere-se à desigualdade dos iguais. "Desde que, vendo uma coisa, a visão desta faz com que penses numa outra, desde então, quer haja semelhança ou dessemelhança, necessariamente o que se produz é uma recordação?” (PLATÂO, 1983, p. 78). Temos aqui não apenas uma ideia que nos transporta para o sentido geral do símbolo, mas também para a ideia de símbolo arquetípico. Pois em "Fédon" proclama-se que o conhecimento é uma rememoração: para estender significações é preciso ir além do objeto, é também necessário que "antes tenhamos tido ocasião de conhecer esse ser, de que se aproxima o dito objeto, ainda que imperfeitamente" (PLATÃO, 1983, p. 78).

Também Agostinho (1996) faz alusão à memória em "Confissões", no trecho da obra intitulado "O Palácio da Memória". Nesta, a memória é apresentada suntuosamente. Para falar dela afirma que transcende a si mesmo chegando até àquele que o criou. Agostinho explicita que na memória se encontram imagens ${ }^{3}$ que são fruto de percepções.

Tudo isto realizo no imenso palácio da memória. Aí estão presentes o céu, a terra e o mar com todos os pormenores que neles pude perceber pelos sentidos, exceto os que já esqueci. É lá que me encontro a mim mesmo, e recordo as ações que fiz, o tempo, lugar, e até os sentimentos que me dominaram ao praticá-las. É lá que estão também todos os conhecimentos que recordo, aprendidos ou pela experiência própria ou pela crença no testemunho de outrem (AGOSTINHO, 1996, p. 268).

Agostinho também discorre sobre a força da memória como algo infinitamente amplo.

Ora, esta potência é própria de meu espírito e pertence à minha própria natureza. Não chego, porém a apreender todo o meu ser. Será porque o espírito é demasiado estreito para conter a si mesmo? Então

\footnotetext{
${ }^{3}$ Cassirer (1994) retoma à questão de que o pensamento se expressa por imagens, quando afirma que "não podemos pensar sem imagens (p. 96).
} 
onde está o que de si mesmo não encerra? Estará fora e não dentro dele? Mas como é que o não contém? (AGOSTINHO, 1996, p. 268).

“A memória é o ventre da alma" (AGOSTINHO, 1996, p. 273), e se alimenta da alegria e da tristeza. Por fim, o autor tratará da "memória das coisas ausentes", afirma que é na memória que as coisas encontram paralelos, reconhecimento. "Nomeio a palavra memória e reconheço o que nomeio. Onde o reconheço senão na própria memória? Mas, então está ela presente a si mesma, pela sua imagem, e não por si própria?" (AGOSTINHO, 1996, p. 274). É pela reminiscência, que significa carregar na memória traços do que se busca, que é possível reconhecer algo ao encontrá-lo. Quando alega que a alegria é só Deus, busca questionar a possibilidade da memória em alguma reminiscência. De alguma forma ele conclui que Deus habita dentro dele e não fora.

Agostinho, na obra "Confissões" (1996), ao declarar como foi seu processo de aprender a falar, faz uma descrição do uso dos sinais na linguagem.

Retinha tudo na memória quando pronunciavam o nome de alguma coisa, e quando, segundo essa palavra, moviam o corpo para ela. Via e notava que davam ao objeto, quando o queriam designar, um nome que eles pronunciavam. Esse querer era-me revelado pelos movimentos do corpo, que são como que a linguagem natural a todos os povos e consiste na expressão da fisionomia, no movimento dos olhos, nos gestos, no tom da voz, que indica a afeição da alma quando pede ou possui e quando rejeita ou evita. Por este processo retinha pouco a pouco as palavras convenientemente dispostas em várias frases e frequentemente ouvidas como sinais de objetos. Domando a boca segundo aqueles sinais, exprimia por eles as minhas vontades (AGOSTINHO, 1996, p. 46-47).

Agostinho (1996) traça comentários sobre os sentidos diversos da Bíblia, abrindo a questão para a possibilidade do tratamento polissignificativo dos termos. Abordou os signos de um modo bem amplo, não se atendo apenas aos signos linguísticos. Tratou de duas funções sígnicas, a primeira representativa, a qual aponta para um sentido e que para além de si significa alguma coisa ao espírito, enquanto a outra função trata de apresentar o signo de modo mais direto aos sentidos, por exemplo a palavra, na representação sonora de um objeto. 
Na obra "De Magistro" (1980), Agostinho utiliza o termo sinal para designar a palavra ou gesto que apresenta um sentido único, como por exemplo, a palavra porta, ou o gesto que aponta para a porta para indicá-la.

Tanto Jung como Cassirer interpretam os sinais como designações de um sentido dado por convenção, enquanto os símbolos apontam para diversas possibilidades contemplativas e interpretativas. Observamos que estes autores partem das mesmas perspectivas que foram pré-trabalhadas na filosofia de Platão e Santo Agostinho.

Jung (1977), ao estudar os símbolos, priorizando os religiosos como reflexos de uma estruturação psíquica compartilhada pela humanidade, anunciou que o inconsciente pode se expressar por meio de uma gama simbólica imensa, e que estes símbolos portam uma quantidade considerável de energia psíquica, de modo condensado. $\mathrm{O}$ autor considerou que os símbolos emergentes do inconsciente tratam de comunicar aspectos da maior relevância para o indivíduo e para a sua comunidade.

Por meio do perscrutar minucioso e profundo destes símbolos, a pessoa realiza a obra de conhecimento de si mesma e no percurso de uma maior compreensão de si há a revelação do outro e do mundo. Esta força de conhecimento de si entendeu como sendo o caminho que leva o ser humano ao religioso. "Na psique humana, em sua camada mais profunda (ID), existe uma força que impulsiona o homem constantemente a Deus" (BIRK, 1998, p. 71).Deste modo, o sentimento religioso se torna um "a priori" que se realiza em diferentes espacialidades, na expressão de diversas sociedades humanas. As religiões se espacializam e se tornam a expressão deste instinto religioso, que, por sua vez, se manifesta por meio de códigos simbólicos originados pelos homens, mulheres, crianças e jovens que vivenciam a religião.

As religiões são expressões simbólicas de uma força enraizada na psique humana e que utilizam, para sua expressão, códigos simbólicos tornando-os identificados às sociedades que os produzem. Por consequência, as espacialidades religiosas são geradas em condições submetidas ao tempo e ao espaço. Contidos nas espacialidades os símbolos criam possibilidades novas de atuação, dependendo dos significados gerados e compartilhados pelas comunidades. Sugere-se, então, que os símbolos arquetípicos são criadores de realidades e conformadores de espacialidades, 
partindo do pressuposto que emergem do humano e nele encontram significado, força e partilha social.

Há um leque de compreensões possíveis que podem ser conjugadas a fim de se compreender os limites das espacialidades. Para tanto, é importante levar em consideração a relação, direta, intensa e constante, entre o coletivo e o individual, o exterior e o interior, o consciente e o inconsciente, a expressividade das diversas linguagens e os campos gerados por elas, a metáfora e a atitude.

Espírito e matéria são sintetizados e reintegrados por meio dos símbolos. Não menos importante é citar que o Eu e o Outro assumem posições dialogantes frente à presença simbólica. Eliade (1996) definiu o símbolo como pertencente à substância da vida espiritual. Para o autor, os símbolos sempre existirão a fim de comunicar, parcelas mais profundas da realidade. $\mathrm{O}$ autor afirma que o pensamento simbólico precede qualquer forma de linguagem e razão discursiva. Eliade concorda com Jung no concernente aos aspectos de possibilidade de aprofundamento do ser em contato com os símbolos. "As imagens, os símbolos e os mitos não são criações irresponsáveis da psique, elas respondem a uma necessidade e preenchem uma função: revelar as mais secretas modalidades do ser" (ELIADE, 1996, p. 8-9).

O sagrado se expressa em linguagem metafórica, conforme Ricoeur (2006, p. 192), a linguagem religiosa "é uma variedade da linguagem poética", e a poética referese ao "poder de fazer corresponder a redescrição da realidade ao poder de levar as ficções da imaginação à palavra" (RICOEUR, 2006, p. 192). O autor afirma que é com a base da poética que a linguagem religiosa revela então seu caráter específico.

O fato de que muitas espacialidades religiosas são construídas tendo em vista a hermenêutica do texto sagrado, o que inclui os mitos, evidencia a característica da função da linguagem simbólica, que reúne, doa sentidos, junta e integra significados a fim de apresentar-se como um sistema organizado, bem definido e gerador de identidades.

Assim o campo de comunicados que se estabelece em uma dada espacialidade religiosa, veiculados pelo texto religioso, é essencialmente metafórico.

O que é então a metáfora? É a extensão da denotação pela transferência de noções a novos objetos, que resistem a essa transferência. Então uma pintura pode ser chamada cinzenta literalmente e triste metaforicamente. A metáfora não é outra coisa do 
que a aplicação de um atributo familiar a um novo objeto, que primeiro resiste, depois cede à sua aplicação (RICOEUR, 2006, p. 177).

A metáfora une pensamento ao sentimento pela via da imaginação e a imaginação é $\mathrm{Musa}^{4}$ inspiradora dos poetas. É possível realizar uma aproximação de sentidos relacionando a inspiração à própria espiritualidade, estabelecendo um símbolo feminino para sua representação, como o fez Jung. A linguagem poética é também a linguagem do inconsciente, portadora de símbolos carregados de sentido e jamais extinguíveis. Desta forma, Ricoeur entra em consonância com a perspectiva junguiana.

(...) as verdadeiras metáforas são intraduzíveis. Só as metáforas de substituição podem receber uma tradução que restaure sua significação própria. As metáforas de tensão são intraduzíveis porque criam significação própria. Dizer que são intraduzíveis não significa que não podem ser parafraseadas, mas a paráfrase é infinita e não esgota a inovação do significado (RICOEUR, 2006, p. 172).

A linguagem religiosa fundamenta-se em símbolos, em metáforas, são comunicações do mundo vivido em aproximação ao mundo dos mistérios. As metáforas são verbalizações dos sentidos simbólicos enraizados em um universo psíquico de totalidade, onde a razão e o sentimento encontram-se entranhados. Na sacralização do espaço os próprios elementos naturais e os elementos originados de construções culturais se metamorfoseiam em símbolos e são narrados de modo mitológico e metafórico.

"A tarefa da geografia cultural é apreender e compreender essa dimensão da interação humana com a natureza e seu papel na ordenação do espaço" (COSGROVE, 2003, p. 103). As culturas religiosas em sua força de expressão simbólica comunicam sentidos coletivos ao mesmo tempo em que estes sentidos se expressam em uma camada coletiva do psiquismo. Conforme Jung (1997), as representações coletivas também carregam fortes energias condensadas, e se diferenciam das representações do inconsciente pessoal por estarem situadas em um campo de sentido comunitário. As representações do inconsciente coletivo são mobilizadas pelos arquétipos, que dão uns toques sociais, coletivos, às experiências humanas, independentes do local aonde venham a transcorrer.

\footnotetext{
${ }^{4}$ Musa é um termo que possui sua origem na mitologia grega e é utilizado para identificar nove deusas, filhas de Zeus, que inspiravam os homens nas artes e nas ciências.
} 
Arquétipos são tipos antigos, marcas psíquicas que se repetem e que delineiam experiências comuns. "Pelo fato do inconsciente ser a matriz espiritual, ele traz consigo a marca indelével do criador" (JUNG, 1989b, p. 16). É ali que se dá, conforme o autor, o nascimento das formas de pensamento.

Jacobi (1990) afirma que o inconsciente coletivo constitui-se de formas antigas e típicas de vivências e comportamentos comuns à espécie humana. Esta afirmativa implica na existência de uma possibilidade de funcionamento psíquico herdado.

Jung (1989b) considera a experiência do todo no uno, e podemos entender que esta lógica também permeou sua demonstrativa de inconsciente pessoal vinculado ao inconsciente coletivo. Existe um todo no qual tudo encontra unificação, e a partir deste todo surgem as singularidades, onde tudo é particularizado. Os arquétipos, como formas para as imagens compartilhadas pela espécie humana, são a expressão da totalidade psíquica. A ideia de Deus, de certo modo, também inspira no mundo religioso, imagens de totalidade que se personificam em singularidades. "O inconsciente é a raiz de todas as experiências de unidade (dharmakâya); é a raiz de todas as formas arquetípicas ou naturais (sambhoga-kâya) é a condicio sine qua non do mundo, das manifestações exteriores (nirmâna-kaya)" (JUNG, 1989b, p. 20).

A Roda do Sol pode ser útil para representar a ideia do Uno que se expressa em partes. Para Jung (1989a), ela é uma imagem arquetípica, que se encontra dividida em quatro ou oito partes. É uma imagem bastante antiga, podendo ser atribuída às eras mesolítica e paleolítica, já encontrada em esculturas da Rodésia (África). “A roda do Sol rodesiana é, portanto, uma visão original, provavelmente a imagem solar arquetípica" (JUNG, 1989a, p. 35). Esta imagem é encontrada em diversos períodos da história humana e em diversas localidades geográficas. "Podemos presumir que a invenção da roda se originou mesmo desta visão. Muitos de nossos inventos se originam de antecipações mitológicas e de imagens primordiais" (JUNG, 1989a, p. 35), e até mesmo a mentalidade científica originou-se da "matriz de nossa mente inconsciente" (JUNG, 1989a, p. 35). 


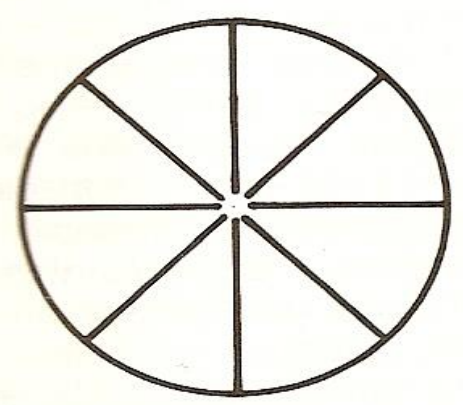

Figura 01: Roda do Sol

Fonte: JUNG, 1987, p.35.

Assim, abordar a Geografia da Religião, tendo em vista as representações simbólicas, utilizando a perspectiva junguiana para o entendimento simbólico, significa dirigir o olhar para os representantes pessoais que se enraízam na coletividade, e que se expressam individualmente, sem perder seu caráter de totalidade. "A multiplicidade é decididamente ilusória quando se sabe que todas as formas singulares provêm da unidade indistinguível da matriz psíquica que se situa nas camadas profundas do inconsciente" (JUNG, 1989b, p.24).

Chevalier e Gheerbrant (2005) apontam no dinamismo simbólico, a função indicada como "ordem exploratória", significando que "o símbolo investiga e tende a exprimir o sentido da aventura espiritual dos homens, lançados através do espaçotempo" (CHEVALIER; GHEERBRANDT, 2005, p.26). Uma aventura que percorre espacialidades e que sofre as influências destas, ao mesmo tempo em que as influencia. Esta aventura exploratória é também a aventura de possuir e controlar, o mundo torna-se objeto de domínio, no qual as sombras psíquicas são também projetadas.

Conforme Jung (1990b), a personalidade humana abrange duas partes, a parte consciente e a parte inconsciente. Cabendo ao conhecido e explicado a porção consciente e ao desconhecido e indefinido a porção inconsciente. $\mathrm{O}$ autor trabalha com as instâncias do feminino e do masculino, localizando-as como energias arquetípicas constitutivas da psique do sujeito. Verificou que existe a presença de elementos correlatos ao simbólico feminino na psique masculina e elementos simbolicamente masculinos na psique feminina. Jung (1977) apresenta estas formas psíquicas inconscientes como dois arquétipos: anima e animus ${ }^{5}$.

\footnotetext{
${ }^{5}$ A anima está presente na psique masculina, enquanto o animus compõe a psique feminina.
} 
$\mathrm{Na}$ afirmativa junguiana a psique é composta pelo movimento que inclui o jogo das polaridades, na instância do inconsciente existem aspectos que são projetados e negados como parte de si pelo consciente, assim as sombras pessoais e coletivas encontram vazão e se espacializam por meio da ação.

Observou as polaridades também na formação dos arquétipos e constatou que onde um arquétipo se manifesta claramente pela consciência seu contraposto aparece como sombra.

Apresenta-se, na figura $\mathrm{N}^{\circ}$ 2, a ideia da estrutura do funcionamento psíquico, baseado na concepção de Jung, que se fundamenta em posicionar os elementos constitutivos da psique humana em constante fluxo relacional. No funcionamento do psiquismo humano não há elementos estanques, todos intercambiam.

O consciente, como instância do conhecido e controlado, é o veículo pelo qual a personalidade individual se expressa no meio coletivo. A atuação "solar" diz respeito ao modo como a consciência se manifesta, discriminando, compreendendo e agindo conforme leis próprias. A atuação "lunar" refere-se ao inconsciente e à sua própria forma de se manifestar. Esta atuação, simbolicamente, foi chamada de lunar por conta de seus aspectos de contemplação e de não controle. 


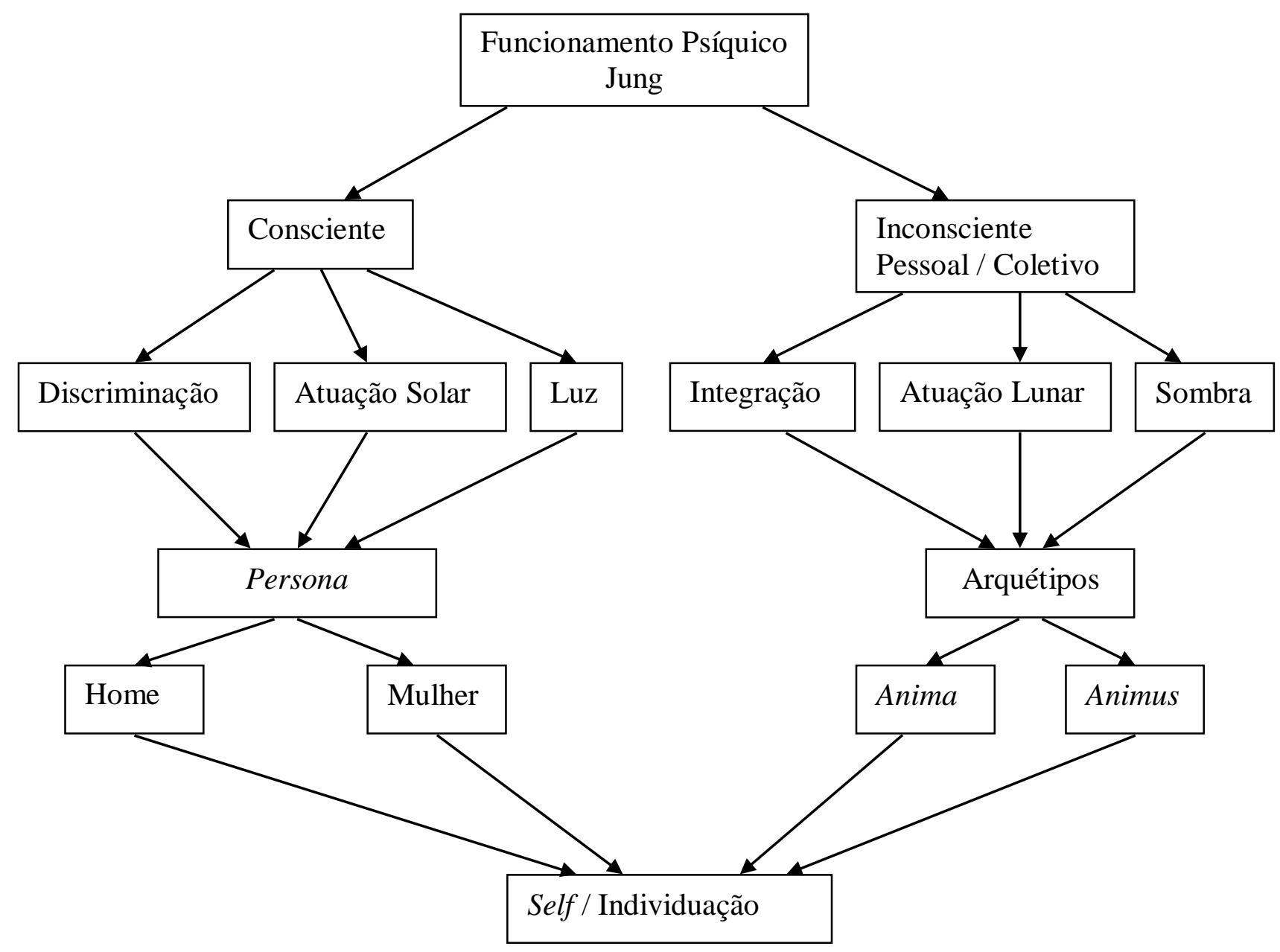

Figura 02: Funcionamento Psíquico - Jung

Fonte: Org. SCHLÖGL, E. 2012.

No processo global de interação psíquica, formula-se um caminho de individuação, uma proposta de totalidade integrativa rumo ao centro de si mesmo, self.

O si-mesmo pode ser caracterizado como uma espécie de compensação do conflito entre o interior e o exterior. Esta formulação não seria má, dado que o si-mesmo, tem o caráter de algo que é um resultado, uma finalidade atingida pouco a pouco e através de muitos esforços. Assim, pois, representa a meta da vida, sendo a expressão plena dessa combinação do destino a que damos o nome de indivíduo: não só do indivíduo singular, mas de um grupo, em que um completa o outro, perfazendo a imagem plena (JUNG, 1990a, p. 114).

Dada a complexidade do pensamento junguiano, a Figura $n^{\circ} 02$ não pretende ser a expressão completa e sintética do funcionamento psíquico, em Jung. A intenção é apenas mostrar um vislumbre desta ordenação e salientar a ideia de que todos os elementos interagem dinamicamente entre si. 
Para o autor (1990a) o núcleo saudável, o self, não representa a verdade, a beleza, o conhecimento, a força ou a sabedoria absoluta, representa apenas a possibilidade de integração de todas as forças psíquicas que integram a psique humana. Uma das tarefas para a realização desta integração é o confronto com a própria sombra, com aqueles aspectos negados em si mesmo e projetados nos outros. Assim, o processo de tornar-se "individido" é um impulso que ganha força na medida em que o consciente e o inconsciente interagem, de modo a aceitar a luz ao mesmo tempo em que se reconhece a presença das sombras.

O self é também um símbolo, é a integração das possibilidades, a visada múltipla e ampla sobre si mesmo, e também a transcendência de si gerada pelo encontro profundo com a própria imanência. "Escolhi a expressão "si-mesmo" (selbst) para designar a totalidade do homem, a soma de seus aspectos, abarcando o consciente e o inconsciente" (JUNG, 1990b, p. 87).

Estas forças psíquicas se transformam em inclinações, e atitudes que se espacializam remetendo-se aos espaços culturais, que são analisados pelos geógrafos e geógrafas na intenção de encontrar, nos desdobramentos do viver humano, o entendimento das modelagens que imprime no ambiente. É valioso compreender as projeções da sombra também nas espacialidades a fim de verificar as forças modeladoras que estas imprimem ao ambiente.

Tudo isto implica em perceber que os espaços possuem "alma", ou seja, a presença material possui uma vinculação direta com o imaterial (desejos, sonhos, pensamentos e sentimentos da humanidade). Deste modo nas espacialidades também há a presença invisível das energias arquetípicas.

A forma de agir das pessoas no mundo segue inclinações pessoais e coletivas, e possuem suas próprias formas simbólicas, modos de ver e interpretar. Isto tudo resulta em modelos interativos, que se articulam vinculados às espacialidades arquetípicas, ou seja: ao primado simbólico original que thes insufla energia e orienta suas inclinações.

\section{SOMBRAS ARQUETÍPICAS PROJETADAS NO ESPAÇO}

No artigo: "Arquétipos Arquétipos, Fantasmas e Espelhos", de Maurício 
Waldman (2008), o autor também afirma que na organização do espaço geográfico se encontram os arquétipos como modeladores das ações dos sujeitos.

Expressão de um determinado modo de relação com a natureza, o arquétipo induz direcionamentos dos fluxos presentes no inconsciente, ele mesmo parte da natureza que habita o corpo do homem, emanação sem a qual não seria possível pensar a dimensão do humano (WALDMAN, 2008, p. 45).

Waldman ao compreender as relações humanas no espaço e no tempo, verifica a importância das imagens arquetípicas, que se fazem presentes por meio das expressões simbólicas originadas do imaginário humano. Os arquétipos, quando manifestos pelo viés da sombra ${ }^{6}$, ganham dimensão de força nas projeções, e acabam por gerar símbolos de força opressora, envolvendo o predomínio de alguns sobre outros, ou ainda, como afirma Waldman (2008), a domesticação da sensibilidade que passa pela domesticação do corpo e que coloca para negros, mulheres, crianças, e seguidores de determinadas religiões, em patamares de subordinação aos a conceitos que muitas vezes lhes negam o direito à existência compartilhada em termos de igualdade. Nesse sentido, o eurocentrismo é formado a partir da sombra do arquétipo do dominador, do "herói". O centro é ocupado pelos países europeus, cabendo a eles, o controle das periferias. O centro adquire poder e força de para submeter os diferentes a uma categoria inferior.

Colocando o fenômeno da perseguição da religião conhecida como Fé Bahá'í em análise psicogeográfica podemos dizer que o islã shi' $i$, no contexto da Persia Pérsia, por conta do surgimento do Movimento Babí e da Fé Bahá 'í, ocupava o centro madálico mandálico ${ }^{7}$ daquele cenário geográfico, configurando espacialidades religiosas a partir de elementos simbólicos tidos como principais e genuínos, enquanto o diferente, o periférico, recebia a carga da projeção simbólica do mal. Na Fé Bahá'í e em seus seguidores a sombra do mal foi projetada, portanto o discurso de perseguição aos bahá'ís assumiu uma atitude de "limpeza do mal", que não passava de uma projeção de sombra não identificada assim pela consciência coletiva dos islã shíí.

\footnotetext{
${ }^{6}$ Refere-se aos aspectos obscuros da personalidade, que na maioria das vezes são relacionados ao que as pessoas chamam de "maldade".

7 A mandala, conforme Jung (1990b), é um símbolo que traduz a unidade e a totalidade, e que coloca valores em uma escala articulada a partir daquele que ocupa a posição central.
} 
Os estereótipos étnicos e raciais em sua relação com o espaço, no qual velhos mitos são muitas vezes revividos, produzem um mosaico de medidas que Waldman (2008) chamou de arquétipo espacial.

O mito da eterna luta entre o bem e o mal, muitas vezes ganhou força significativa no combate entre governanças. Na na justificativa de ataques territoriais, bem como na subordinação de determinados sujeitos considerados como partícipes do "lado mau", enquanto aos bons restaria o controle e as benesses de uma vida "protegida".

Waldman (2008) defende que vivemos um novo arquétipo espacial, diferente do arquétipo vivido em outros momentos históricos. Ao analisar a espacialidade arquetípica do período medieval europeu, diz:

\begin{abstract}
Assim sendo, é perceptível um imaginário topológico nitidamente diferenciado de seu precedente feudal. Na idade média, o arquétipo espacial estava eivado de conotações hoje entendidas como arcaicas ou ingênuas. Explicitariam este imaginário medieval: a explicação ptolomaica do universo, com uma Terra plana ocupando seu centro; Jerusalém como o omphalos do mundo habitado e em decorrência disto, do universo; o registro, nos mapas medievais de toda sorte de bestas e animais fantásticos, procedentes de uma biologia maravilhosa; o domínio de concepções mágicas relativas aos ventos, às marés, aos vulcões, aos terremotos e tufões; crença de que o espaço habitado coexistiria com o Jardim do Éden e com os reinos imaginários como o de Prestes, João e assim por diante (WALDMAN, 2008, p. 50).
\end{abstract}

Conforme o autor, um novo arquétipo, substitutivo do anterior, formula-se a partir do repúdio às forças da natureza. As cartografias elaboradas no ocidente, afirmam o eurocentrismo e banem elementos mitológicos.

A cartografia faz uso, consciente ou não, de um aparato simbólico cujas significações decorrem das expectativas espaciais pertinentes a um determinado padrão civilizatório e sendo assim, seu papel extrapola a mera apreensão ou aferição objetiva do espaço (WALDMAN, 2008, p. 50).

Percebe-se, segundo o mesmo autor, que a Europa passa a ocupar a parte superior dos mapas, lugar que anteriormente era ocupado pela Ásia. "Jerusalém, que era costumeiramente destacada no centro do mundo, perde esta localização, com a descoberta da rotundidade da terra" (WALDMAN, 2008, p. 50). 
A ideia da Terra Redonda mobiliza também uma nova compreensão de mundo. Onde está o centro do mundo? Basta girar a esfera e o centro se desloca. A própria ideia contemporânea da relativização da verdade configura uma nova espacialização arquetípica, na qual elementos diversos ocupam ora o lugar da centralidade, ou de periferia, conforme o ângulo sob o qual cada fenômeno é percebido.

O mapa contemporâneo é matematizado, conteúdos originados das diferentes mitologias são banidos das cartografias, mas o destaque dado à Europa e a ideia de posição que sugere a existência dos "países de cima" e dos "países de baixo", denota denotam uma clara topografia do poder e de projeção de sombras.

Simbolicamente, o bem e o belo estão colocados acima, enquanto o mal se relaciona aos mundos de baixo. Um dos criadores da bioenergética ${ }^{8}$, Lowen (1982), afirma que algumas ideias primitivas se associaram ao cristianismo antigo, o que favoreceu a simbolização da barriga como a morada dos espíritos da escuridão ali residiam os habitantes da "região de baixo", "aí também na morada do diabo, é onde queima o fogo da sexualidade”. LOWEN, (1982, p. 83).

O corpo da terra e o corpo do ser humano são simbolizados e tornam-se imagens agregadora de sentidos e significados. A cabeça humana, lugar onde a coroa é posta, simboliza a valorização da mente racional. Jung (1976) afirma que Agostinho relacionava a imagem divina à alma rationalis;, então, "onde está o intelecto, onde está a mente, onde está a razão, à qual compete investigar a verdade, aí Deus tem a sua imagem" (JUNG, 1976, p. 36).

Conforme Elias (1994), o termo "civilização" foi uma apropriação de um termo nativo em voga na França e na Inglaterra a partir do século XVI, e que implicava em considerar a civilização como algo em processo, o que incluía incluindo a ideia de evolução.

No decorrer da história, civilizações consideraram como bárbaras ou primitivas outras culturas que se diferenciavam delas. O "evoluído" era o "civilizado", e o civilizado era o que se outorgava o direito de conquistar, e imprimir sua marca em outras culturas que, portanto, eram desvalorizadas e desterritorializadas.

O Arquétipo Espacial do Ocidente, ao valorizar o geométrico e o matemático, o retilíneo e o uniforme, guarda íntimas relações com a

\footnotetext{
${ }^{8}$ A bioenergética é uma das escolas de pensamento e de prática da psicologia somática.
} 
discriminação racial. Em desajustes com os dinamismos corporais, orgânicos, naturais e cósmicos que sempre foram valorizados pelas culturas antigas, este arquétipo molda estereotipias e traços pejorativos para com o outro.(...)(WALDMAN, 2008, p. 55).

Deste modo, o autor conclui que o primado da racionalidade, tido como um princípio geral e organizador, acaba sendo excludente e discriminatório. Causa a exclusão do não racional. Assim, os sentimentos reprimidos atuam de modo a gerar comportamentos motivados por ódios, angústias, profanação e terror, o que Waldman (2003) chamou de "reserva pulsante do irracional" (p. 55).

Este território, pleno de sentimentos reprimidos, de fluxos pervertidos do inconsciente social, está circunscrito a um mapa, a uma Cartografia, cujos significados topológicos decorrem daquela dessacralização dos valores e das crenças que durante a maior parte da história humana constituíram seu espólio mais valioso. (WALDMAN, 2008, p. 55).

Waldman (2008) busca resgatar o suprimido, aquele que se torna socialmente oprimido, analisa a força arquetípica atuante na espacialização geográfica do mundo levando em consideração a "sombra" e sua projeção destinada ao "Outro".

Nesta perspectiva, a dimensão de sombra projetada na contemporaneidade, não engloba mais os monstros marinhos que devoravam homens e nem todos aqueles seres temidos que caracterizassem caracterizavam o domínio do mal sobre a terra, mas destinam-se aos corpos daqueles que são considerados como diferentes, os "Outros", e aí estão os imigrantes, as mulheres, os negros, os explorados pelo trabalho, ao que incluímos à lista lista na qual incluímos os seguidores das, as religiões perseguidas e sobre as os quais se projetam nossas próprias sombras.

Nesse espaço de ser "Outro", as religiões "diferentes" podem ser submetidas ao ataque vigoroso do poder religioso vigente. São, muitas vezes, perseguidas e “demonizadas", de um modo brutal. O espaço geográfico, físico, de liberdade, lhes é negado aos seus seguidores, na mesma medida em que ao no seu espaço simbólico são projetadas imagens do mal e do medo.

Um exemplo disto é o que a Fé Bahá'í apresenta em sua narrativa histórica. Conforme Gouvion e Jouvion (1996), no Irã, a perseguição feita aos bahá ís é incessante, tendo passado por diferentes formas desde a época do Báb até os dias atuais. Em 1907, o Sháh Muhammad Ali, aprovou uma lei eleitoral para a exclusão das pessoas 
bahá'ís. Entre 1921 e 1922 o Sháh Reza fez votar uma lei na qual vários bahá ís deveriam ser privados da aposentadoria. Em 1925, qualquer candidato a cargo público obrigatoriamente deveria declarar sua religião, sendo que era proibida a contratação de bahá 'ís; como também da mesma forma, somente os casamentos muçulmanos, cristãos, judeus e zoroastristas passavam a ser declarados oficiais. Os casais bahá'ís eram considerados adúlteros, e seus filhos ilegítimos. Entre 1930 e 1932 os bahá 'ís que eram suboficiais foram rebaixados de postos, e os que eram oficiais, expulsos. O Ministro da Educação proibiu a impressão de literatura bahá'í. Em 1934, escolas bahá 'ís são foram fechadas e, em 1941, com o Shá’h Muhammad Reza no poder, nove membros de uma Assembleia Espiritual são feitos prisioneiros. Em 1951, discípulos seguidores de Bahá 'u'lláh são acusados de conluio com os comunistas e, em 1955, quando o exército ocupa edifícios nos quais acontecia a Convenção Bahá'i da Comunidade Nacional Iraniana, o Ministro do Interior dá deu ordens para a erradicação total do que ele chamou de seita bahá'í. Em 1978, muitos bahá'ís foram assassinados, queimados, ou torturados por todo o Irã. "Em algumas localidades, os homens são arrastados até as mesquitas e ameaçados de ver suas mulheres e filhos degolados diante de seus olhos se não renegarem sua fé" (JOUVION, GOUVION, 1996, p.168). Também a Constituição de 1979 é destrutiva para os bahá'ís, pois decreta o afastamento total dos membros bahá 'ís na da vida iraniana. Os autores também declaram que em 1981, foram feitas 30 execuções, e na maioria das vezes os bahá 'ís eram também torturados.

$\mathrm{O}$ arquétipo de sombra projetada sobre os bahá 'ís custou a vida e a liberdade de muitos.

Segundo Waldman (2008), a exclusão dos desejos, dos afetos, das fantasias, e a absoluta exclusão do outro de si mesmo, leva ao não reconhecimento das características comuns, que conduz conduzem os seres humanos a solidarizarem-se uns com os outros.

A sombra negada em si e projetada nos outros priva estes outros das espacialidades comuns e compartilhadas e, priva-os em última instância, de qualquer tipo de espacialidade concretizada sobre a Terra. Matar e aniquilar aquele que porta a dimensão do negado, da sombra, torna-se comportamento comum aplicado a diferentes etnias, o que inclui as religiões.

A interdição e o controle espacial, com ancoragem no imaginário, vinculando o arquétipo do dominador sobre o dominado, causam uma clara distribuição de papéis e 
de funções que definem as espacialidades vivenciadas por cada grupo. Nesse movimento também estão os arquétipos do feminino e do masculino, que recebem significações e interdições em decorrência das interpretações que se estabelecem e que, de certo modo, se oficializam nas diferentes culturas.

Conforme Alves (2010), as sociabilidades masculinas e as femininas foram diferenciadas culturalmente, as espacialidades masculinas de socialização foram marcadas por jogos e diversão, enquanto as femininas giravam em torno do espaço doméstico. Aos homens estava destinado o espaço público da aventura, e às mulheres o espaço reservado do recato e do cuidado para com os filhos. $\mathrm{O}$ autor afirma que esta dicotomia relacional definiu papéis e espacialidades, o que enrijeceu e naturalizou tornou naturais algumas identidades de gênero.

Alves (2010) analisa que a construção de espaços, baseada nas diferenças entre os sexos, se ancorou-se em determinantes biológicos, que acabaram gerando significados culturais construídos.

Foi nesta nessa perspectiva de dicotomias que as espacialidades femininas da Pérsia, no surgimento do Movimento Babí e da Fé Bahá'í eram vivenciadas. Uma pequena parcela dos espaços era permitida às mulheres, inclusive do espaço religioso que estava sob os ditames masculinos. A Fé Bahá'í propõe algumas mudanças, estimulando as mulheres a vivenciarem novas espacialidades. A ênfase inicial foi a de ampliar a participação feminina no âmbito educacional, proporcionando às mulheres o contato com o conhecimento científico e a possibilidade de se tornarem-se profissionais.

Deste modo, enquanto o feminino era tratado como uma projeção arquetípica de sombra, a Fé Bahá'í recupera o arquétipo da anima, tirando do feminino as significações negativas e sombrias de gênero, lançando luz às sombras amplia espacialidades femininas atribuindo-lhes voz própria.

Khan (2003) afirma que desde o começo, as comunidades bahá ís da Terra Santa se envolveram com o desenvolvimento da educação de meninas e meninos. Com ênfase constante no processo educativo, 'Abdu'l-Bahá estabeleceu planos para a criação de uma escola para meninas em Haifa; por conta da forte oposição, este plano não chegou a se concretizar-se, mas criaram-se outras formas de facilitar a educação de meninas. Inclusive, algumas netas de 'Abdu'l-Bahá, receberam seu suporte apoio a fim 
de conseguirem estudar em colégios em Beirute e no Cairo, e mais tarde na Inglaterra, já nos primeiros anos do século vinte.

Por meio da educação feminina, novos arquétipos são mobilizados, entre eles a possibilidade de surgirem heroínas bahá 'ís que possuíam possuidoras de conhecimentos e eram tão letradas quanto os homens, inclusive com conhecimentos profundos sobre conceitos religiosos do próprio islamismo, como é o caso de Táhirih.

A inclusão da escolarização feminina, objetivada pelos bahá 'is, favoreceu a entrada das mulheres em novos domínios, o que possibilitou a emergência da anima em um contexto geográfico no qual o animus ocupava o centro da consciência e à anima restavam espacialidades derivadas da projeção de sua sombra.

Conforme Jung (1976), o termo animus relaciona-se ao espírito e à razão, enquanto o termo anima relaciona-se ao Eros Materno. Assim, o arquétipo nominado animus representa a força do Logos Paterno em oposição a à anima, que representa o Eros Materno.

Possibilitar às meninas a vivência de espacialidades voltadas à educação significava permitir às mulheres a experiência de totalidade no desenvolvimento de sua força intelectual, representada pelo Logos e permitir aos meninos a vivência de relacionamentos, vínculos e percepção de sensibilidades significa oferecer-lhes a experiência de totalidade no desenvolvimento de sua capacidade afetiva, integrando em si a força do Eros Materno.

Do mesmo modo que a anima, assim também o animus tem um aspecto positivo. Sob a forma do pai expressam-se não somente opiniões tradicionais como também aquilo que se chama "espírito" e de modo particular certas concepções filosóficas e religiosas universais, ou seja, aquela atitude que resulta de tais convicções. Assim o animus é também um "psicopompos", isto é, um intermediário entre a consciência e o inconsciente, e uma personificação do inconsciente. Da mesma forma que a anima se transforma em um Eros da consciência, mediante a integração, assim também o animus se transforma em um Logos; da mesma forma que a anima imprime uma relação e uma polaridade na consciência do homem, assim também o animus confere um caráter meditativo, uma capacidade de reflexão e conhecimento á à consciência feminina (JUNG, 1976, p. 14).

As espacialidades religiosas para homens e mulheres se diversificam a partir do relacionamento positivo ou negativo com os símbolos arquetípicos. A partir daquilo 
que se estabelece nessa relação novas formas de ação no espaço se tornam possíveis, isto inscreve no solo do planeta a sacralização de espacialidades diversas.

\section{REFERÊNCIAS}

ALVES, I. G. Divisão sexual dos espaços: práticas e sociabilidades femininas e masculinas nas vilas operárias do sul de Santa Catarina (Brasil 1930-1960), Nuevo Mundo Mundos Nuevos, Debates, 2010, Disponível em: <http://nuevomundo.revues.org/60227>.

AGOSTINHO. Confissões. São Paulo. Editora Nova Cultura Ltda, 1996.

De Magistro. São Paulo. Abril Cultural, 1980.

BACHELARD, Gaston. A Poética do Espaço. São Paulo: Martins Fontes, 2005.

BONNEMAISON, Joel..Viagem em torno do território. p.83-131. In: CORRÊA, Roberto Lobato; ROSENDHAL, Zeni (orgs.). Geografia Cultural: um século(3). Rio de Janeiro: Bertrand Brasil, 2002.

BOURDIEU, Pierre. Le sens pratique. Paris: lés Edictions de Minuit, 1980.

BIRK, Bruno Odélio. O sagrado em Rudolf Otto. Porto Alegre: EDIPUCRS, 1998.

CAMPBELL, John. O Poder do Mito. São Paulo: Palas Atena, 1993.

CASSIRER, Ernest. Ensaio sobre o homem. Introdução a uma filosofia da cultura humana. São Paulo: Martins Fontes, 1997.

CHEVALIER, Jean; GHEERBRANT, Alain. Dicionário de símbolos. Rio de Janeiro: José Olympio, 2005.

COSGROVE, Denis. Em direção a uma geografia cultura radical: problemas da teoria. In: CORREAA, Roberto Lobato; ROSENDHAL, Zeni (orgs.). Introdução à geografia cultural. Rio de Janeiro: Bertrand Brasil, 2003.

ELIADE, Mircea. Imagens e símbolos. Ensaio sobre o simbolismo mágico religioso. São Paulo: Martins Fontes, 1996.

ELIAS, Norbert. O processo civilizador. Rio de Janeiro: Jorge Zahar, 1994.

FRANZ, L. Von. O processo de individuação. In: JUNG, Carl G. . O homem e seus símbolos. Rio de Janeiro: Nova Fronteira, 1977.

FRIES, Henrich. Dicionário de Teologia., São Paulo: Edições Loyola, 1970.

GIL FILHO, Sylvio Fausto. O espaço sagrado. Estudos em geografia da religião. Curitiba: Ibepex, 2008.

GOUVION, Collete; JOUVION, Philippe. Os jardineiros de Deus: a Fé Bahá'í na perspectiva de dois jornalistas. Brasília: Editora Planeta Paz, 1996. 
JACOBI, Jolande. Complexo arquétipo símbolo na psicologia de C. G. Jung. São Paulo: Cultrix, 1990.

JUNG, C. Gustav. Estudos sobre o simbolismo do si-mesmo. Petrópolis, R.J: 1976.

O homem e seus símbolos. Rio de Janeiro: Nova Fronteira, 1977.

. Fundamentos de psicologia analítica. Petrópolis. Vozes, 1989a.

. Psicologia e religião oriental. Petrópolis. Vozes, 1987 b.

. O eu e o inconsciente. Petrópolis. Vozes, 1990a.

. Psicologia e religião. Petrópolis. Vozes, 1990b.

KAST, Verena. A dinâmica dos símbolos. Fundamentos da psicoterapia junguiana. São Paulo: edições Loyola, 1994.

KHAN, Janet A. and Peter J. Kahn. Adavancemente of women: a bahá'í perspective. Wilmette: Bahá'í Publishing Trust, 1998.

LOWEN, Alexander. A espiritualidade do corpo. São Paulo: Pensamento, 1983.

NEUMANN, Erich. A Grande Mãe. Um estudo fenomenológico da constituição feminina do inconsciente. São Paulo: Cultrix, 2006.

PlATÃo. Diálogos: O Banquete, Fédon, Sofista, Politico. São Paulo: Abril Cultural, 1983.

RICOEUR, Paul. Percurso do reconhecimento. São Paulo: Edições Loyola, 2006.

SCHLÖGL, Emerli. Não basta abrir as janelas. O simbólico na formação do professor. Dissertação de mestrado. PUC/PR, 2005.

Conformação simbólica das espacialidades arquetípicas femininas: um estudo das comunidades bahá'ís de Curitiba e região- Paraná. Tese de doutorado. UFPR, 2012.

TUAN, Yi-Fu. Espaço e lugar: a perspectiva da experiência. Trad. Lívia de Oliveira. São Paulo: Defel, 1983.

WALDEMANN, Maurício. Arquétipos, fantasmas e espelhos. GEOUSP, Publicação da Pós Graduação do Departamento de Geografia da FFLCH-USP, São Paulo (SP), Vol.1, No.23, 2008, p.44-63.

Recebido: $12 / 05 / 2014$

Received: 05/12/2014

Aprovado: 19/10/2014

Approved: 10/19/2014 